\title{
Plain packaging of tobacco products: Lessons for the next round of implementing countries
}

\author{
Joanna E. Cohen ${ }^{1}$, Suzanne Zhou', Mark Goodchild ${ }^{3}$, Shane Allwright ${ }^{4}$
}

Australia was the first country in the world to implement tobacco plain and standardized packaging, with plain packs appearing on retailer shelves in December 2012. Plain packaging laws standardize the appearance of packs by prohibiting all design features (including colours, shapes, images, logos, textures/ finishes, scents, and promotional text) other than those explicitly permitted. A brand and variant name in a plain font may appear on the pack, and the packs are also required to carry health warnings labels plus other required consumer information. Packs must appear in standard colours, with Pantone 448C, a drab green/brown colour, as the main background colour of the pack ${ }^{1}$.

In June 2020, the final remaining legal challenge to Australia's tobacco plain packaging laws was decided in favour of Australia. The World Trade Organization's (WTO's) Appellate Body found that tobacco plain packaging contributed to its objective of reducing tobacco use and exposure, that it was not more traderestrictive than necessary to achieve that public health objective, and that it did not infringe any intellectual property rights under the WTO Agreements ${ }^{2}$.

The Appellate Body's decision ends a decade of litigation against Australia's tobacco plain packaging laws. This litigation included a challenge by tobacco companies in the High Court of Australia (decided in Australia's favour in 2012) an investor-state dispute brought by Philip Morris Asia (PMA) under a bilateral investment treaty with Hong Kong (dismissed in 2015 on the grounds that PMA had abused its rights under the treaty $)^{4}$, and a challenge brought in the World Trade Organization, which was decided in Australia's favour at the first instance in $2018^{5}$ and has now been confirmed on appeal. Unsuccessful legal challenges were also launched against plain packaging in the $\mathrm{UK}^{6}$, France ${ }^{7}$, Norway ${ }^{8}$, and Ireland ${ }^{9}$. These legal challenges formed part of a broader campaign by the tobacco industry to stop or delay the implementation of plain packaging. The challenges have now been definitively ended by the WTO Appellate Body, whose status as the final appeal mechanism for the multilateral trading system should give other countries the confidence to move ahead with the measure without fear of challenges under trade or intellectual property law.

In addition to litigation, the tobacco industry has used other tactics to oppose plain packaging legislation such as: lobbying; PR/media campaigns in both print and online media (using familiar arguments such as the 'Nanny state'); threatening manufacturing plant closures, claiming increased illicit trade and increased stealing from retailers; and using third-party front groups to make its arguments $^{10,11}$.

When it cannot prevail in stopping the implementation of plain packaging, the tobacco industry ensures it exploits any loopholes, for example by introducing brand names with colour or concept descriptors ${ }^{12-14}$.

\author{
AFFILIATION \\ 1 Department of Health, \\ Behavior and Society, Johns \\ Hopkins Bloomberg School \\ of Public Health, Baltimore, \\ United States \\ 2 McCabe Centre for Law and \\ Cancer, Melbourne, Australia \\ 3 Health Promotion \\ Department, World Health \\ Organization, Geneva, \\ Switzerland \\ 4 Centre for Global Health, \\ School of Medicine, Trinity \\ College Dublin, The University \\ of Dublin, Dublin, Ireland

\section{CORRESPONDENCE TO} \\ Joanna E. Cohen. Department \\ of Health, Behavior and \\ Society, Johns Hopkins \\ Bloomberg School of Public \\ Health, 2213 McElderry \\ Street, 4th Floor, \\ Baltimore, Maryland \\ 21205, United States. \\ E-mail:jcohen@jhu.edu \\ KEYWORDS \\ plain packaging, tobacco \\ products, standardized \\ packaging, tobacco control \\ policy, low and middle income \\ countries
}

Received: 12 November 2020 Accepted: 12 November 2020 
Australia conducted rigorous and extensive research to inform the specifics of their plain packaging requirements and most other countries that subsequently introduced plain packaging legislation adopted or adapted similar requirements ${ }^{15}$. However, while there are many similarities, there are also differences in countries' specific plain pack requirements, such as differences in the products covered (e.g. most countries exclude e-cigarettes), pack dimensions, and pack edges.

In 2019, Thailand was the first low-to-middle income country (LMIC) to introduce plain packaging and its experiences may be helpful to other LMICs. Due to intense lobbying by the tobacco industry, with Philip Morris International and various front groups arguing that plain packaging was a violation of trademark and intellectual property rights, the Thai legislation was delayed for seven years. When the WTO finally found in favour of plain packaging in June 2018, Thailand moved quickly. The Thai plain packaging regulation was drafted over the next few months and came into effect by September 2019.

As of October 2020, 17 countries have adopted plain packaging: Australia, Canada, France, Ireland, Israel, New Zealand, Norway, Saudi Arabia, Singapore, Slovenia, Thailand, Turkey, UK, Uruguay, Belgium, Hungary, and the Netherlands. Many more have progressed plain packaging laws and regulations to varying extents.

\section{Conclusions}

Plain packaging addresses the obligations to implement effective packaging and labelling measures under Article 11 of the WHO Framework Convention on Tobacco Control (FCTC) and to comprehensively ban tobacco advertising, promotion and sponsorship under FCTC Article 13. There is no need for countries to reinvent the wheel; they can follow the example of other countries with regard to the wording of their legislation as well as arguments and strategies to counteract tobacco industry opposition. There are also valuable resources that countries can use, including plain packaging evidence summaries and toolkits such as the Campaign for Tobacco-Free Kids' Plain Packaging Toolkit ${ }^{16}$, WHO's report on the evidence, design and implementation of tobacco product plain packaging ${ }^{17}$, and Cancer Council Victoria's Plain Facts $^{18}$.
While legal challenges against plain packaging have been unsuccessful, great care is nonetheless required in drawing up legislation. Those involved in drafting plain packaging legislation should work with lawyers and others with experience in countries that have already enacted plain packaging to ensure that their plain packaging legislation is strong and that potential loopholes are minimized.

Plain packaging has great potential globally to change societal perceptions and thereby denormalise use of tobacco products especially among youth, who are vulnerable to tobacco industry marketing strategies. This is particularly important in LMICs where the tobacco industry is aggressively marketing their products. Many LMICs therefore have a unique opportunity to prevent further growth of the tobacco epidemic through plain packaging along with other evidence-based tobacco control measures. It is now time for all countries to move forward with tobacco plain packaging to help save lives by reducing tobacco-related death and disease.

\section{REFERENCES}

1. Moodie C, Hoek J, Scheffels J, Gallopel-Morvan K, Lindorff K. Plain packaging: Legislative differences in Australia, France, the UK, New Zealand and Norway, and options for strengthening regulations. Tob Control. 2019;28:485492. doi:10.1136/tobaccocontrol-2018-054483

2. Appellate Body. Australia - Certain Measures Concerning Trademarks, Geographical Indications and Other Plain Packaging Requirements Applicable to Tobacco Products and Packaging. WT/DS435/AB/R, WT/DS441/AB/R. https://docs.wto.org/dol2fe/Pages/SS/directdoc. aspx?filename $=\mathrm{q}: / \mathrm{WT} / \mathrm{DS} / 435 \mathrm{ABR} \cdot \mathrm{pdf} \&$ Open $=$ True. Published June 9, 2020. Accessed November 12, 2020.

3. High Court of Australia. JT International SA v Commonwealth of Australia. HCA 43. Matter No S409/2011. http://eresources.hcourt.gov.au/ downloadPdf/2012/HCA/43. Published 2012. Accessed November 12, 2020.

4. Philip Morris Asia Limited v. The Commonwealth of Australia, UNCITRAL, PGA Case No. 2012-12. italaw website. https://www.italaw.com/cases/851. Accessed November 12, 2020.

5. Panel Report. Australia - Certain Measures Concerning Trademarks, Geographical Indications and Other Plain Packaging Requirements Applicable to Tobacco Products and Packaging: Reports of the Panels. WT/DS435/R, WT/ DS441/R, WT/DS458/R, WT/DS467/R. https://docs. wto.org/dol2fe/Pages/SS/directdoc.aspx?filename=q:/ WT/DS/435R.pdf\&Open=True. Published June 28, 2018. Accessed November 12, 2020. 
6. England and Wales Court of Appeal. British American Tobacco UK Ltd \& Ors, R (on the application of) v The Secretary of State for Health [2016] EWCA Civ 1182. https://www.bailii.org/ew/cases/EWCA/Civ/2016/1182. html. Accessed November 12, 2020.

7. Conseil d'Etat. Décision n 399117, 399789, 399790, 399824, 399883, 399938, 399997, 402883, 403472, 403823, 404174, 404381, 404394, Société JT International SA, Société d'exploitation industrielle des tabacs et des allumettes, Société Philip Morris France SA et autres. https://www.conseil-etat.fr/fr/arianeweb/ CRP/conclusion/2016-12-23/399117?download_pdf. Published December 23, 2016. Accessed November 12, 2020.

8. Oslo County Court. Swedish Match Ltd. v. Ministry of Health and Care Services et al. Case No.: 17-110415TVIOBYF. Campaign for Tobacco-Free Kids website. https://www. tobaccocontrollaws.org/litigation/decisions/no-20171106swedish-match-v-the-ministry-o. Published November 6, 2017. Accessed November 12, 2020.

9. JTI Ireland Ltd v Minister for Health [2015] IEHC 481. https://www.bailii.org/ie/cases/IEHC/2015/H481.html. Accessed November 12, 2020.

10. Hawkins B, Holden C, Mackinder S. A multi-level, multi-jurisdictional strategy: Transnational tobacco companies' attempts to obstruct tobacco packaging restrictions. Glob Public Health. 2019;14:570-583. doi:10.1080/17441692.2018.1446997

11. MacKenzie R, Mathers A, Hawkins B, Eckhardt J, Smith J. The tobacco industry's challenges to standardized packaging: A comparative analysis of issue framing in public relations campaigns in four countries. Health Policy. 2018;122:1001-1011. doi:10.1016/j.healthpol.2018.08.001

12. Evans-Reeves KA, Hiscock R, Lauber K, Gilmore AB. Prospective longitudinal study of tobacco company adaptation to standardised packaging in the UK: Identifying circumventions and closing loopholes. BMJ Open. 2019;9:e028506. doi:10.1136/bmjopen-2018-028506

13. Scollo M, Occleston J, Bayly M, Lindorff K, Wakefield M. Tobacco product developments coinciding with the implementation of plain packaging in Australia. Tob Control. 2015;24:e116-e122. doi:10.1136/tobaccocontrol-2013-051509

14. Scollo M, Bayly M, White S, Lindorff K, Wakefield M. Tobacco product developments in the Australian market in the 4 years following plain packaging. Tob Control. 2018;27:580584. doi:10.1136/tobaccocontrol-2017-053912.

15. Institute for Global Tobacco Control, Johns Hopkins Bloomberg School of Public Health. Advancing Tobacco Plain and Standardized Packaging in Low- and MiddleIncome Countries: Advice from Experts. https:// www.globaltobaccocontrol.org/sites/default/files/ plain_packaging_report_0.pdf. Published March, 2020. Accessed November 10, 2020.

16. Campaign for Tobacco-Free Kids. Plain Packaging Toolkit: A Practical Guide to Policy Development, Drafting the
Law and Overcoming Tobacco Industry Opposition. https://www.tobaccofreekids.org/plainpackaging. Accessed November 11, 2020.

17. World Health Organization. Plain packaging of tobacco products: Evidence, design and implementation. https://apps.who.int/iris/bitstream/ handle/10665/207478/9789241565226_eng.pdf; jsessionid=853B6E3CB78B3053D4E2C16487BFC5A3? sequence $=1$. Published 2016. Accessed November 11, 2020.

18. Cancer Council Victoria. Plain Packaging: The Facts. https://www.cancervic.org.au/plainfacts. Accessed November 11, 2020.

\section{ACKNOWLEDGEMENTS}

We acknowledge the contribution of Michael lacobelli who synthesized the similarities and differences across countries' plain packaging policies and Prakit Vathesatogkit for the information on the development of Thailand's plain packaging legislation.

\section{CONFLICTS OF INTEREST}

The authors have each completed and submitted an ICMJE form for disclosure of potential conflicts of interest. The authors declare that they have no competing interests, financial or otherwise, related to the current work. S. Zhou reports grants from Australian Department of Health, during the conduct of the study and grants from Australian Department of Foreign Affairs and Trade, outside the submitted work.

\section{FUNDING}

JEC's time for this webinar/editorial is supported by Bloomberg Philanthropies. SZ's time on this editorial is supported by a grant from the Australian Department of Health, and by core funding from Cancer Council Victoria. The McCabe Centre also receives funding from the Australian Department of Foreign Affairs and Trade for its work on law and noncommunicable diseases.

\section{AUTHORS' CONTRIBUTIONS}

SA, JEC and SZ drafted the editorial based on talks presented at the WCTOH webinar entitled 'Plain packaging: lessons for the next round of implementing countries'. MG contributed additional text. All authors reviewed and commented on drafts of the editorial and approved the final version.

\section{PROVENANCE AND PEER REVIEW}

Commissioned; internally peer reviewed. This editorial is based on the talks given by SZ, JEC and Prakit Vathesatogkit at a webinar entitled 'Plain packaging: lessons for the next round of implementing countries' on 29 October 2020 as part of the Leadership Summit on Tobacco Control webinar series, hosted by the 18th World Conference on Tobacco or Health. 